\title{
Suitability of groundwater from the Kherzet Youcef lead-zinc deposit (North-eastern Algeria) for irrigation and drinking water supply
}

Cheddad Souhila ( $\nabla$ cheddadsouha@gmail.com )

, Houari Boumadiene University of Science and Technology

Haouchine Abdelhamid

, Houari Boumadiene University of Science and Technology

\section{Research Article}

Keywords: TME, Quality Standard, SAR, mining pollution, Kherzet Youcef Deposit

Posted Date: November 2nd, 2021

DOI: https://doi.org/10.21203/rs.3.rs-1032713/v1

License: (c) (i) This work is licensed under a Creative Commons Attribution 4.0 International License.

Read Full License 


\section{Abstract}

As part of the hydrogeological study of the Kherzet Youcef deposit, a drilling battery was carried out. The objective of this achievement is the satisfaction of the water needs of the city of Ain Azel (drinking water supply, irrigation and industrial water supply) and even the transfer to other municipalities suffering by the lack of water and the resumption of mining activity at the deposit of Kherzet Youcef.

This water table is located in carbonate formations of Paleo-Neogene age linked to lead-zinc mineralization. Knowledge of water quality and its suitability for human consumption is an obligation. These metals have adverse health effects.

We used the results of Sonarem's analyses between 1973-1979. In addition, we carried out two analyses, during two years 2015 - 2016, on five boreholes. The parameters analyzed are major elements, physical parameters and trace metal elements ( $\mathrm{Zn}, \mathrm{Pb}$ and $\mathrm{Fe})$. The analyses were done by ICP-AES.

In our work, it has been shown that waste water is suitable for use in agriculture. For this we used the electrical conductivity at $25^{\circ} \mathrm{C}$ and those of the sodium adsorption ratio (SAR).

For drinking water supply, monitoring the change in $\mathrm{TME}$ ( $\mathrm{Zn}, \mathrm{Pb}$ and $\mathrm{Fe}$ ) for two years has allowed us to conclude that groundwater in the groundwater table east of the Kherzet Youcef fault is generally acceptable. They are eligible by the quality standard set by Algerian regulations. However, they exceed WHO standards, especially for lead.

We recommend a revision of drinking water quality standards set by Algerian regulations, rigorous monitoring of TME content variation and water treatment before distribution.

\section{Introduction}

In most parts of the world, groundwater is of paramount importance. It is even more so in developing countries, such as Algeria. Groundwater is generally cheaper and aquifers enjoy natural protection from anthropogenic pollution (Calow et al., 2010). It is also a reliable source of supply and buffer against drought (Calow et al., 2010).

Despite this importance, groundwater quality can deteriorate due to many factors influencing its chemical composition and consequently its multiple uses. These factors include lithology, time of residence of water in contact with rocks, ambient temperature and $\mathrm{pH}$, chemical composition of the aquifer, climatic conditions prevailing during formation, quantity of water available in the aquifer and its circulation rate (Soro et al., 2019)

In Algeria, water resources come from renewable and non-renewable surface and groundwater. The exploitation of these resources is very intense with the growing needs related to demographic growth and the accelerated development of economic activities, especially irrigated agriculture and industry (Bouchamal and Achour, 2015) 
Abandoned mines have caused and continue to cause many environmental problems. The heavy metals from these mines are, for the most part, at high levels, and constitute a danger to public health when they manage to contaminate the waters. As a result, heavy metal water pollution in the vicinity of mines has often been reported in the literature (Smith and Bradshaw, 1972; Merrington and Alloway, 1994; Fanfani et al, 1997; Paquette et al, 2000; Jung, 2001; Jabour, 2003).

For the Kherzet Youcef deposit, the volumes of exhalation are large. During the mining period, the mine water was used for the processing of $\mathrm{Zn}$ and $\mathrm{Pb}$ ore. Subsequently, the volumes of the drainage water are greater than the needs of the mine, a decision was made to use them for irrigation of almost 350 ha of agricultural land around the mine.

As part of the hydrogeological study of the Kherzet Youcef deposit, a drilling battery was carried out. A total of ten (10) initial boreholes of $20 \mathrm{l} / \mathrm{s}$ each are carried out. These waters are intended for the drinking water supply of the city of Ain Azel and even neighboring towns.

\section{Material And Methods}

\subsection{Presentation of the study area}

Orographically, the deposit is located within the limits of the Hodna mountain range on the northeastern flank of the Jebel Hadjar Labiod chain, culminating at $1371 \mathrm{~m}$. East of the deposit, there is a vast intermountainous depression, with gentle slopes towards Ain Azel. (Fig. 1)

The polymetallic deposit of Kherzet Youcef recognized since the beginning of the century by the exploitation of the ore of $\mathrm{Zn}$ and $\mathrm{Pb}$. This deposit is associated with a Barremian age carbonate layer. Since the beginning of operation, several water flows, at different amplities, have been recorded. (ENOF, 2002)

Based on available data at the mine level, recorded outflows as a function of operating depth are recorded in Table 1: 
Table 1

Water intake by operating depth (1965-1979)

\begin{tabular}{|c|c|c|}
\hline Nature of work & $\begin{array}{l}\text { Depth } \\
\text { (m) }\end{array}$ & $\begin{array}{l}\text { Water flow rate } \\
(1 / s)\end{array}$ \\
\hline \multirow[t]{2}{*}{ Digging the ventilation shaft I } & $87 m$ & 8 à $10 \mathrm{l} / \mathrm{s}$ \\
\hline & $90 m$ & $5 \mathrm{l} / \mathrm{s}$ \\
\hline \multirow[t]{2}{*}{ Digging the extraction shaft III } & $90 \mathrm{~m}$ & $11 \mathrm{l} / \mathrm{s}$ \\
\hline & $98 m$ & 250 passes à $97 \mathrm{l} / \mathrm{s}$ \\
\hline Operating level 835 & $157 m$ & 5 sources avec une débit moyen $11 \mathrm{l} / \mathrm{s}$ \\
\hline Operating level 775 & $217 \mathrm{~m}$ & 6 sources avec un débit moyen de $3,3 \mathrm{l} / \mathrm{s}$ \\
\hline
\end{tabular}

The reserves between levels 835 and 775 (800,000 tons) were extracted from 1979 to 1987 by the chamber and pillar method.

Between the year 1982 and 1990 the water flows evolved as shown in the graph of Fig. 2.

The arrivals observed at the bottom of the Kherzet Youcef mine during the period from 1982 to 1990, gradually evolved from $298 \mathrm{~m}^{3} / \mathrm{h}$ to almost $1000 \mathrm{~m}^{3} / \mathrm{h}$ before the accident of 2/June 1990 .

\subsection{Sampling}

We have old chemical analysis data on wastewater from 1974 to 1990, as well as groundwater analyses on wells carried out by ENOF.

As part of our hydrogeological study, we monitored the change in trace element (ETM) levels during a period from June 2015 to November 2016.

These samples are manual and are carried out at the head of the borehole. Samples are taken in plastic vials of 1 I capacity. Before the actual sampling, the vial is thoroughly rinsed with the collected water.

\subsection{TMA measurement}

The water samples were previously filtered using a $0.45 \mu \mathrm{m}$ Wattman GFC filter, then analyzed by emission spectroscopy whose source is a plasma generated by inductive coupling (ICPAES).

The role of plasma is to break molecular bonds to produce ions, free atoms so that they are excited.

\section{Results And Discussions}

\section{Origin of the water at the bottom of the mine}


Principal component analysis (PCA) was used to explain the origin at the bottom of the mine. The PCA is a multi-variegated analysis method allowing the simultaneous study of a large number of variables whose total information cannot be visualized because of a space with more than three dimensions (Mouissi and Alyat, 2016). This method would make it possible to clarify the relationships between the variables and the phenomena at the origin of these relationships. The objective is to have information concentrated on a minimum of axis (Ayadi et al., 2008). This method is widely used to interpret hydrochemical data (WHO, 2000).

The statistical analysis of the physico-chemical data was carried out on a data matrix consisting of ten (10) variables and ten (10) samples distributed around the Kherzet Youcef deposit. The statistical software Statistica version 10 was used for data processing.

The correlation matrix gives a first idea of the existing associations between the different variables such as bicarbonate, chlorine, sulphates and $\mathrm{pH}$. These parameters are relatively well correlated with each other (Table 2).

Table 2: Correlation matrix between variables on all stations studied

\begin{tabular}{|c|c|c|c|c|c|c|c|c|}
\hline & $\mathrm{Ca}^{++}$ & $\mathrm{Mg}^{++}$ & $\mathrm{Na}^{+}+\mathrm{K}^{+}$ & $\mathrm{HCO}_{3}{ }^{-}$ & $\mathrm{Cl}^{-}$ & $\mathrm{SO}_{4}^{--}$ & $\mathrm{pH}$ & Depth \\
\hline $\mathrm{Ca}^{++}$ & 1,00000 & & & & & & & \\
\hline $\mathrm{Mg}^{++}$ & 0,044073 & 1,000000 & & & & & & \\
\hline $\mathrm{Na}^{+}+\mathrm{K}^{+}$ & $-0,404123$ & 0,462396 & 1,000000 & & & & & \\
\hline $\mathrm{HCO}_{3}{ }^{-}$ & $-0,143872$ & 0,428250 & 0,619449 & 1,000000 & & & & \\
\hline $\mathrm{Cl}^{-}$ & $-0,231317$ & $-0,101159$ & 0,646032 & 0,015681 & 1,000000 & & & \\
\hline $\mathrm{SO}_{4}^{-}$ & $-0,181831$ & 0,731061 & 0,927202 & 0,574229 & 0,508859 & 1,000000 & & \\
\hline $\mathrm{PH}$ & $-0,057180$ & 0,814775 & 0,475717 & 0,320496 & 0,174403 & 0,678729 & 1,000000 & \\
\hline Depth & 0,300030 & $-0,070292$ & $-0,235833$ & $-0,667114$ & 0,120997 & $-0,108149$ & 0,109819 & 1,000000 \\
\hline
\end{tabular}

The eigenvalues of the correlation matrix make it possible to measure the percentage of the variance explained by each factorial (Fig. 4). The eigenvalue graph shows that the first factorial plane, consisting of the axes $\mathrm{F} 1$ and $\mathrm{F} 2$, represents $66.42 \%$ of the total inertia. It proves to be sufficient to reflect the essence of this inertia. Because if we observe the distribution of the eigenvalues, we find that the main offset occurs just after the first two values, which means that the first two axes are sufficient to represent the information in its entirety.

The graphs resulting from factor analysis, highlight groupings, oppositions and directional trends. The F1 axis expresses $46.37 \%$ of the variance and represents most of the variables in the same direction in a negative way, these are bicarbonate, alkaline earth, sulphates and $\mathrm{pH}$ (Fig. 5). Which expresses the same origin of these variables. For two variables, depth and calcium are related and evolve in the same direction and differ on the F2 axis which expresses $20.05 \%$ of the variance. 
Principal component analysis (Fig. 6) makes it possible to determine the waters according to their origin, the waters belonging to the surface table and the waters coming from the Barremian table, these waters are of bicarbonated character. For water from the bottom of the mine (Pit II) are individualized and do not belong to any group. This can be explained by the change in the chemical quality of the waters after the rock is crushed and the time it takes to store the water at the bottom of the mine before discharging it to the outside.

\section{Kherzet Youcef mine water suitability for irrigation}

In the vicinity of the Kherzet Youcef deposit lies a vast expanse. This area is agricultural land used for potato and cereal crop production.

A decision has been made to use the drainage water of the Kherzet Youcef deposit for irrigation of a perimeter on an area of about 350 ha.

To characterize the irrigability of exhaust water, we use the values of electrical conductivity at $25^{\circ} \mathrm{C}$ and those of the sodium adsorption ratio (SAR).

$$
\text { S.A.R. }=\frac{\left[\mathrm{Na}^{+}\right]}{\sqrt{\frac{\left[\mathrm{Ca}^{2+}\right]+\left[\mathrm{Mg}^{2+}\right]}{2}}}
$$

The SAR is less than 5 (Fig. 7) and waters do not cause the risk of alkalinization of soils (WHO, 2000) (Subramani et al., 2005). The transfer of the samples placed on the irrigation water classification diagram shows that the waters are between the good class (S1) and the middle class (S2) where the danger of alkalinization of the soil is appreciable in soils with fine texture and high exchange capacity.

The exchangeable $\mathrm{Na}+$ ions can replace the alkaline earth ions $\left(\mathrm{Ca}^{2+}\right.$ and $\left.\mathrm{Mg}^{2+}\right)$ of the clays, thus causing the blocking of the soil pores and thus its waterproofing.

\section{Suitability of neogene groundwater for drinking water supply}

The results of analysis of the trace metal elements are shown in Figs. 8, 9 and 10. These values are compared to the limit values set by the Algerian regulations (Decree 11-219 of 12 June 2011) and the limit values set by WHO (WHO 2006). Note that the WHO has no indication regarding the maximum allowable value of iron (WHO 2006). 
For Zn (Fig. 8), the analysis values on all waters sampled do not exceed $1 \mathrm{mg} / \mathrm{l}$. this result remains admissible by the WHO standard set at $3 \mathrm{mg} / \mathrm{l}$ and the Algerian standard, less demanding, set at $5 \mathrm{mg} / \mathrm{l}$.

For Muac (Fig. 9), the majority of assay values are not permissible under the WHO standard (0.01 mg/l). For the Algerian standard, always remains less demanding, $0.05 \mathrm{mg} / \mathrm{l}$.

Only one sample, on borehole 3 dated July 2016, we note that this value is higher than the Algerian standard.

As regards the Fe element, the majority of the values of the results obtained are higher than the maximum value fixed by the Algerian regulations.

\section{Conclusion}

In the context of the hydrogeological study of the Kherzet Youcef deposit, a considerable amount of water must be evacuated in order to resume mining activity.

From the climatic point of view the Ain Azel region is located on a semi-arid climate with very low inputs. The lack of water resources to meet needs (agriculture, drinking water supply or industrial water supply) has led managers to exploit all available resources.

The quality of these resources and their suitability for use is an indispensable parameter.

In our work, it has been shown that waste water is suitable for use in agriculture. For this we used the electrical conductivity at $25^{\circ} \mathrm{C}$ and those of the sodium adsorption ratio (SAR).

For drinking water supply, monitoring the change in TEM ( $\mathrm{Zn}, \mathrm{Pb}$ and $\mathrm{Fe}$ ) for two years has allowed us to conclude that groundwater in the groundwater table east of the Kherzet Youcef fault is generally acceptable. They are eligible by the quality standard set by Algerian regulations. However, they exceed WHO standards, especially for lead.

These trace metal elements ( $\mathrm{Zn}, \mathrm{Pb}$ and $\mathrm{Fe})$ are among the most toxic of soil contaminants. In very small quantities, some are indispensable for the metabolism of living beings, but harm their health in large doses. We recommend a revision of drinking water quality standards set by Algerian regulations, rigorous monitoring of TEM content variation and water treatment before distribution.

\section{References}

1. Ayadi I., Habib H. et Yasmine D., (2016) - Caractérisation physico-chimique, minéralogique et géochimique des sédiments de la retenue du barrage Sidi chahed et des sols du bassin versant de l'oued Mikkés. International Water Ressources Association. XIIIth World Water Conress 1. Montpellier, France. 139-147 
2. Bouchemal F., ACHOUR S. (2015) - Qualité physico-chimique et paramètres de pollution des eaux souterraines de la région de Biskra. Larhys Journal, ISSN 1112-36880, n²2, June 2015, pp. 197-212

3. Calow CR, Mac Doanald AM, Nicol AL, Robins NS. (2010) - Ground water security and drought in Africa: Linking availability, access and demand. Ground Water, 48(2):246-256.

4. ENOF: Entreprise Nationale des Produits Miniers Non Ferreux, (2002) - Situation hydrogéologique du gisement de Kherzet Youcef. 10p.

5. Fanfani L., Zuddas P. et CHESSA A. (1997) - Heavy metals speciation analysis as a tool for studying mine tailings weathering. Journal of geochemical Ecploration 58 (1997) 241-248.

6. Jabour J. L. (2003) - Mine-waste mineralogy and mineralogical perspectives of acid-base accounting. In Environmental Aspects of Mine Wastes (eds. J. L. Jabour, D. W. Blowes and A. I. M. Ritchie). Mineralogical Association of Canada, Vol. 31, 117-145.

7. Jung, M.C. (2001) - Heavy metal contamination of soils and waters in and around the Imcheon Au-Ag mine, Korea. Appl. Geochem, 16: 1369-1375.

8. Merrington G. \& Alloway B. J. (1994) - The flux of $\mathrm{Cd}, \mathrm{Cu}, \mathrm{Pb}$ and $\mathrm{Zn}$ in mining polluted soils. Water, Air and Soil Pollution 73: 333-344, 1994. Kluwer Acadelic Publishers. Printed in the Netherlands.

9. Mouissi S. et Alayat H. (2016) - Utilisation de l'analyse en composantes principales (ACP) pour la caractérisation physico-chimique des eaux d'un écosystème aquatique: cas du las Oubéira (Extrême NE Algérien). Journal mater environnement scientiste. Pages 2028-20508

10. Paquette Y., Blachere A., Lefebvre O., Guise Y. et Barriere J. P. (2000) - Les lacs miniers des exploitations à ciel ouvert du Massif central: qualité et évolution. Chronique de la Recherche minière $n^{\circ} 541$, éd. BRGM, 85-101.

11. Secrétariat Générale de d'état (SGG) (2011) - Décret exécutif n 11-219 du 10 Rajab 1432 correspondant au 12 juin 2011 fixant les objectifs de qualité des eaux superficielles et souterraines destinées à l'alimentation en eau des populations. Journal officiel n³4. Pages 4-6.

12. Smith R. A. H. and Bradshaw A. D. (1972) - Stabilization of toxic mine wastes by the use tolerant plant populations. Transactions of Institution of Mining and Matallurgy (Section A) 81: 230-237.

13. Soro G., Soro T.D., FOSSOU N. MR., ADJIRI O. A., (2019) - Application des méthodes statistiques multivariées à l'étude hydrochimique des eaux souterraines de la région des lacs (centre de la Côte d'Ivoire). International Journal of biological and chemical sciences. 20pages

14. Subramani T., Elango L., and Damodarasamy S. R. (2005) - Groundwater quality and its suitability for drinking and agricultural use in Chithar River Basin, Tamil Nadu, India," Environmental Geology, Vol. 47 1099-1110.

15. OMS (2006) - Norme de qualité de potabilité des eaux, https://www.lenntech.fr/applications/potable/normes/normes-oms-eau-potable.htm

16. O.M.S, (2000) - Directives de qualité pour l'eau de boisson. 2nd Ed., Vol 2, Critères d'hygiène et documentation à l'appui, 1050p. 


\section{Declarations}

Competing interests: the authors declare no competing interests.

\section{Figures}

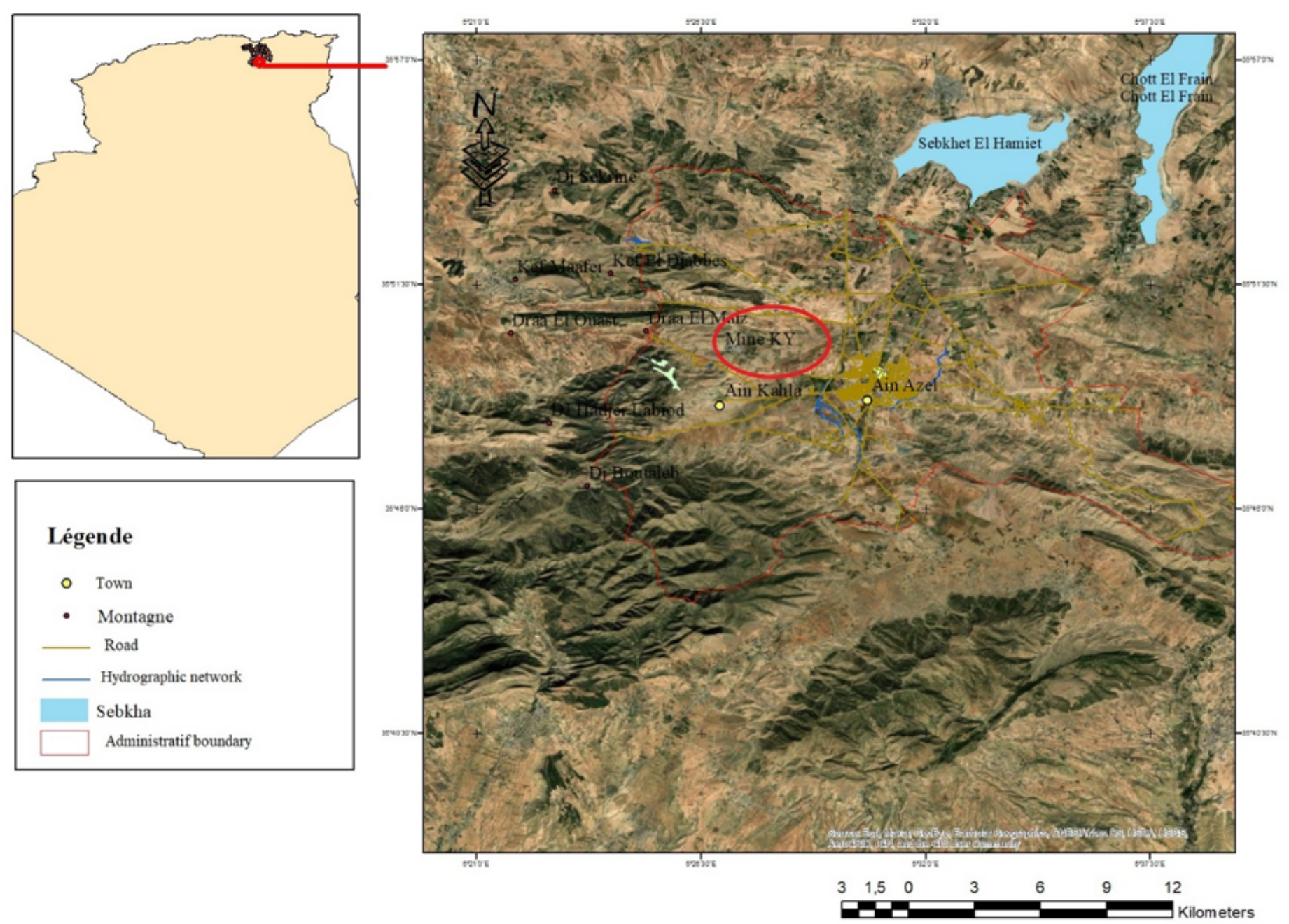

Figure 1

Geographic location of the study area 


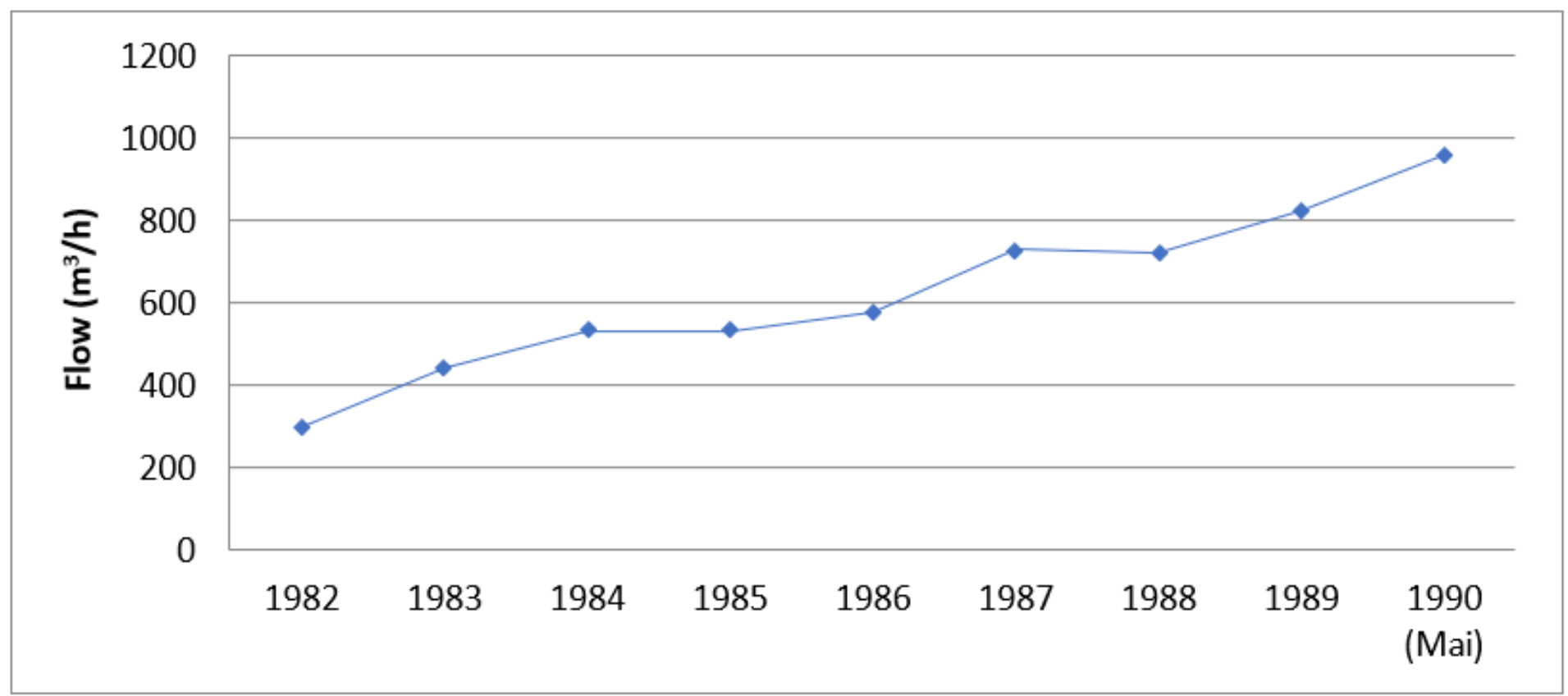

Figure 2

Evolution of the outflow of water at the bottom of the Kherzet Youcef mine (1982-1990)

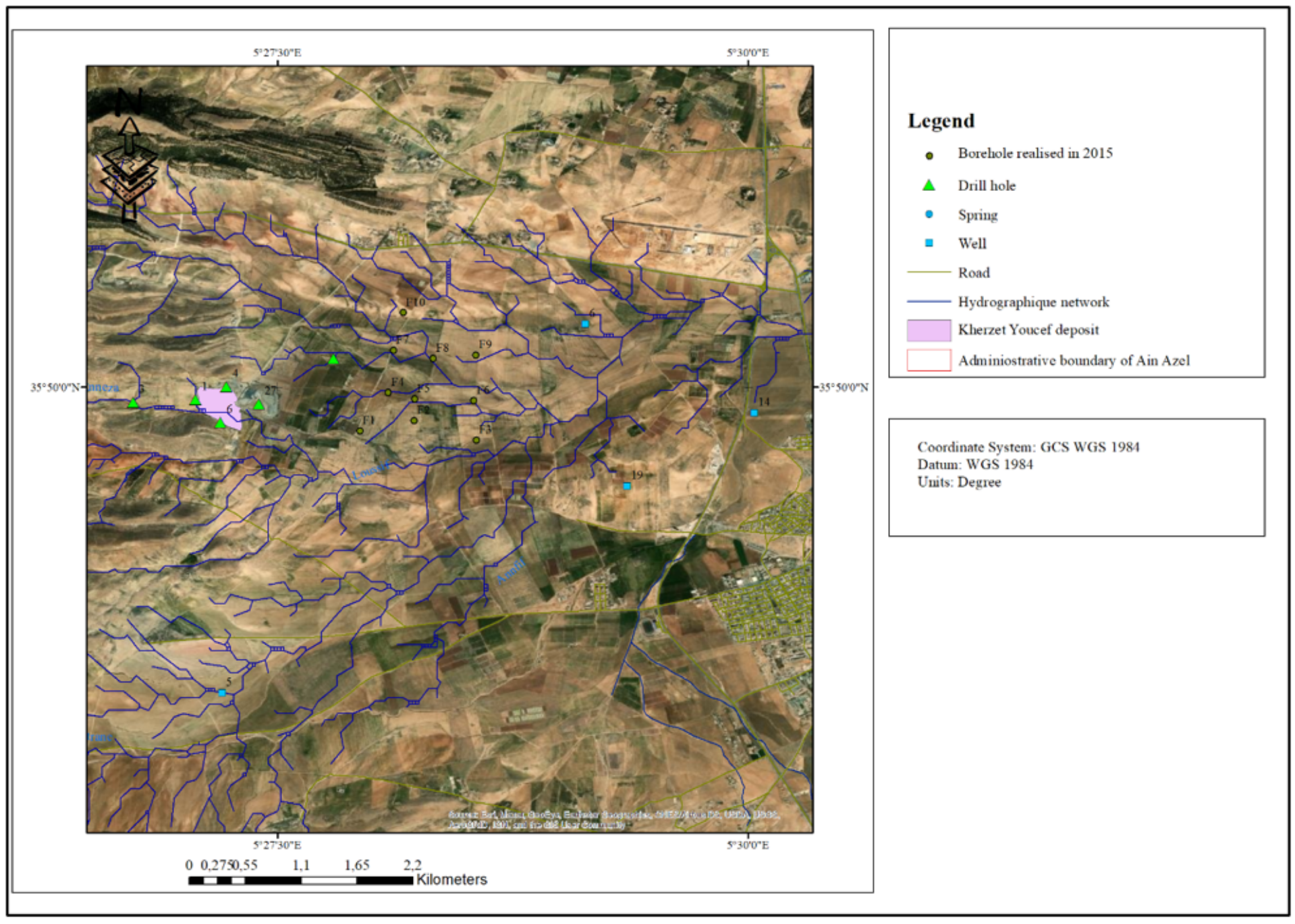


Figure 3

Collection point inventory map

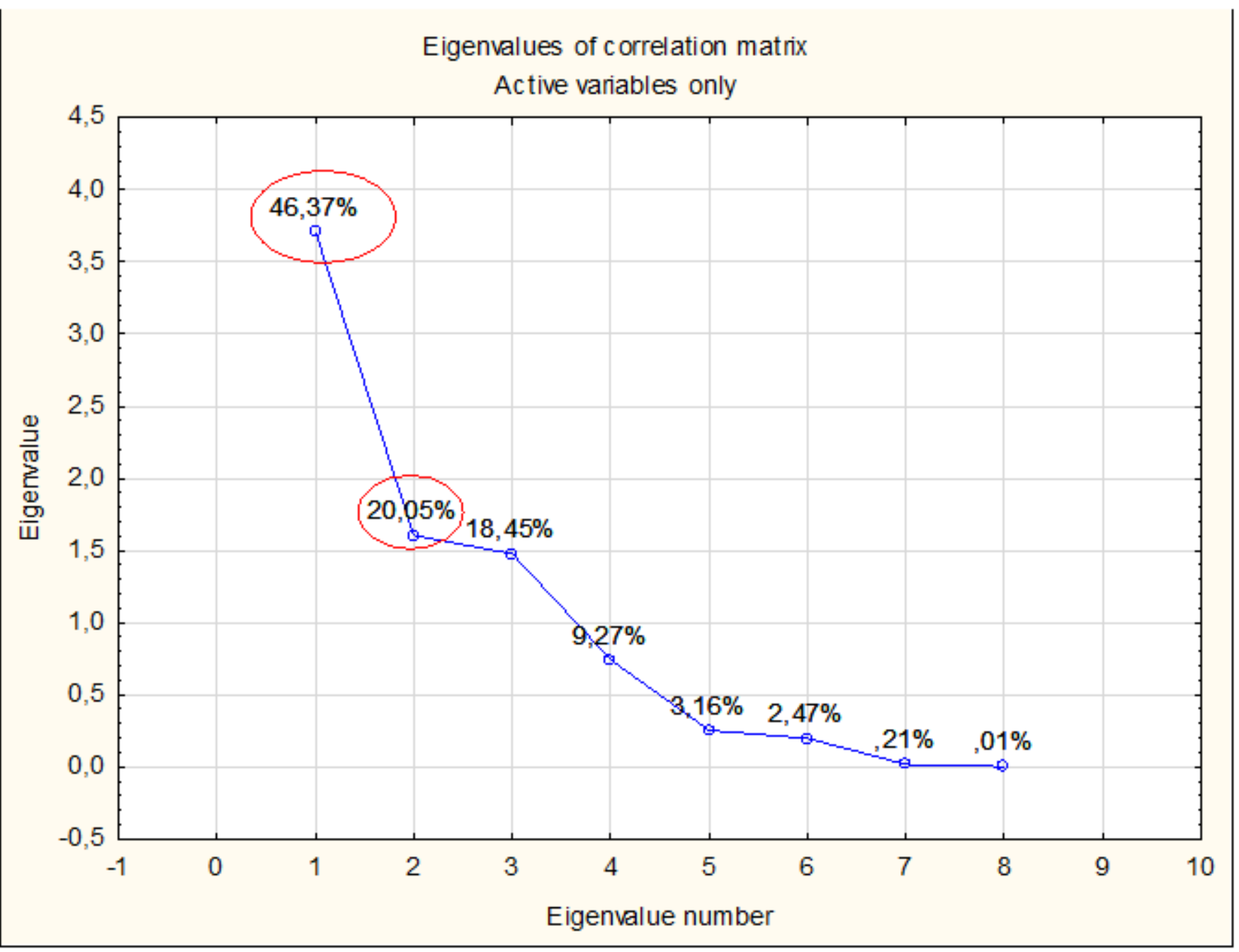

Figure 4

Eigenvalue of correlation matrix 


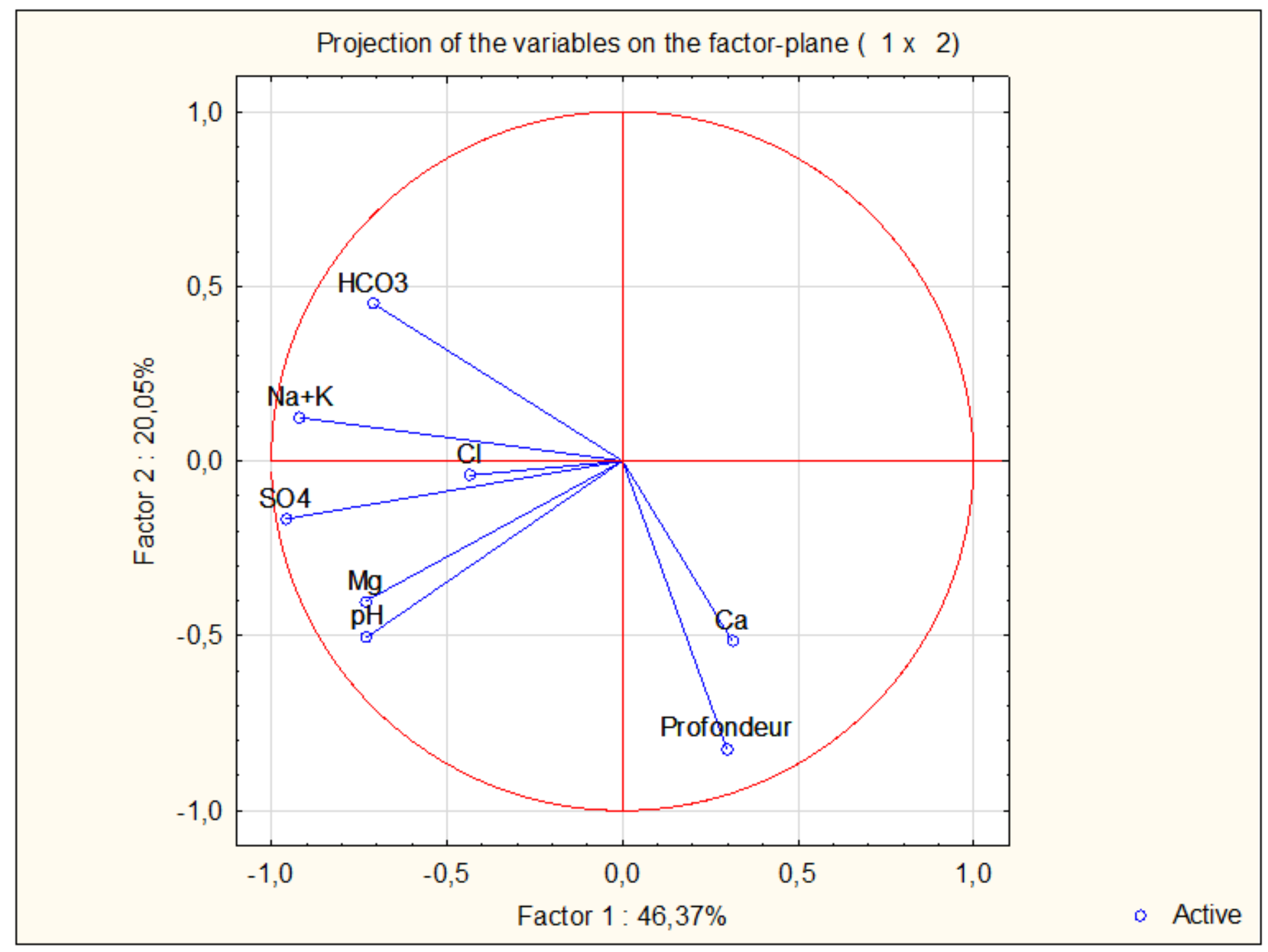

Figure 5

Projection of the variables on the factor-plane (F1-F2) 


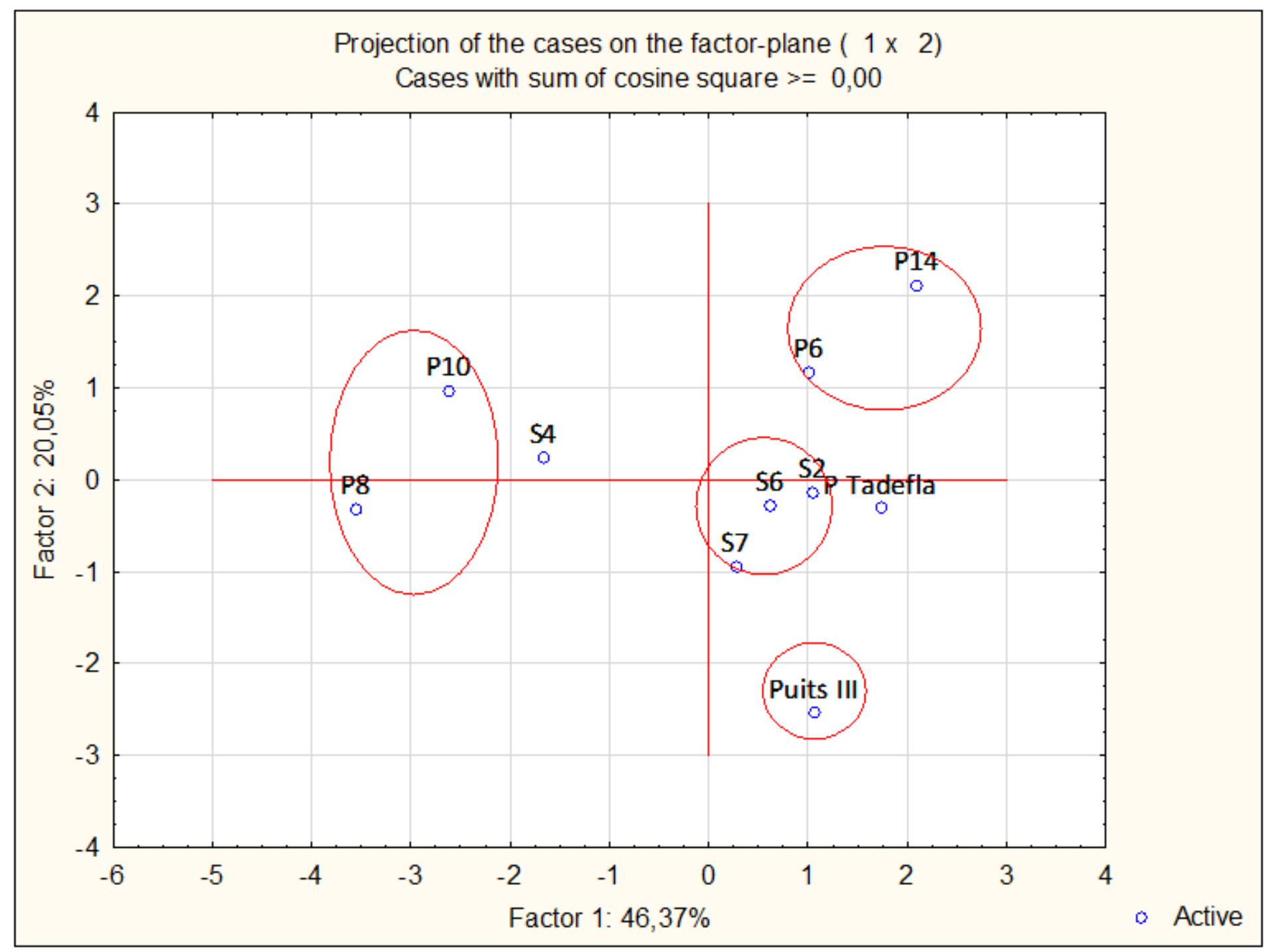

Figure 6

Projection of the cases on the factor-plane (F1-F2) 


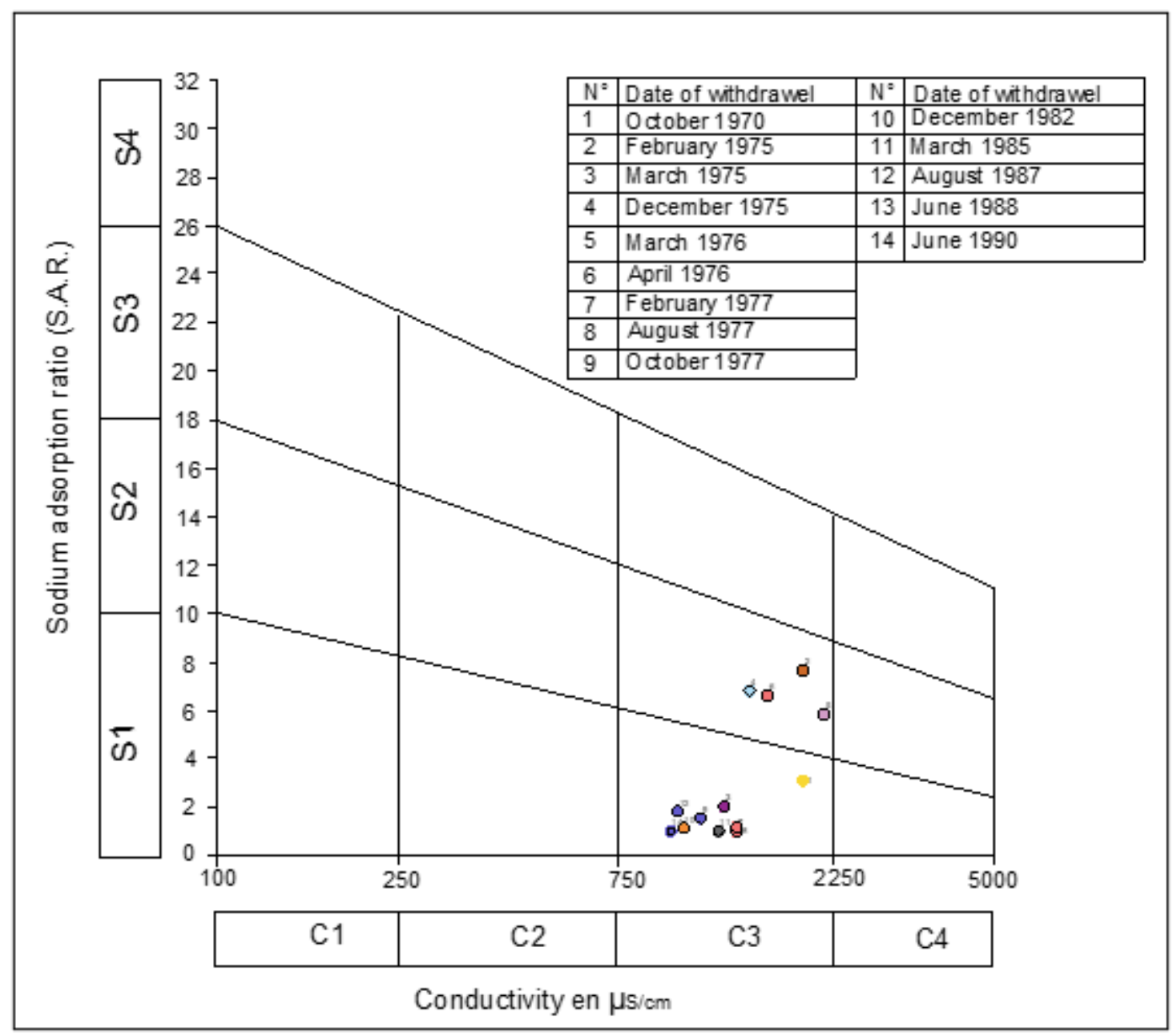

Figure 7

Diagram for the classification of irrigation water according to the SAR 


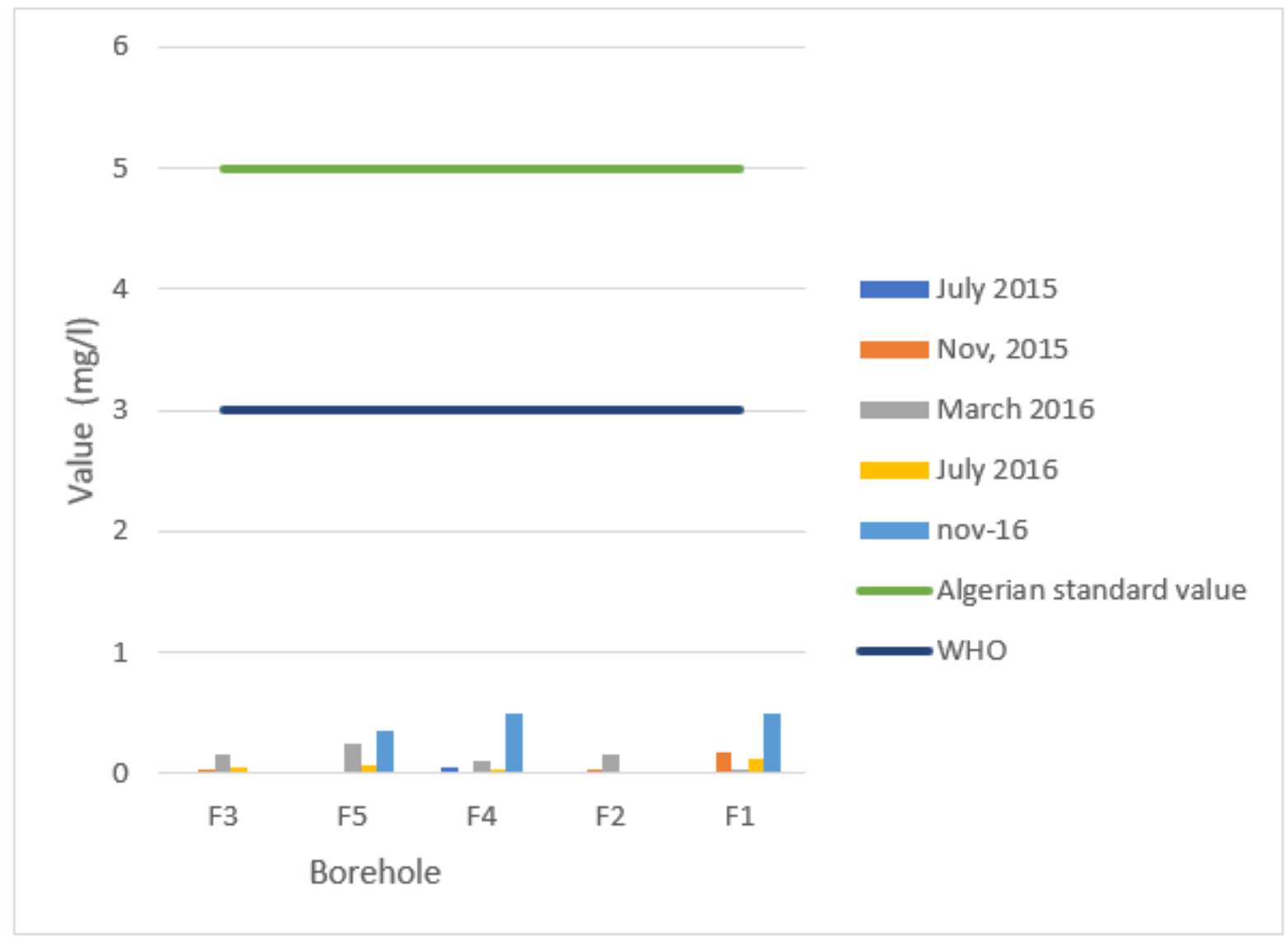

Figure 8

Change in $\mathrm{Zn}$ levels in groundwater 


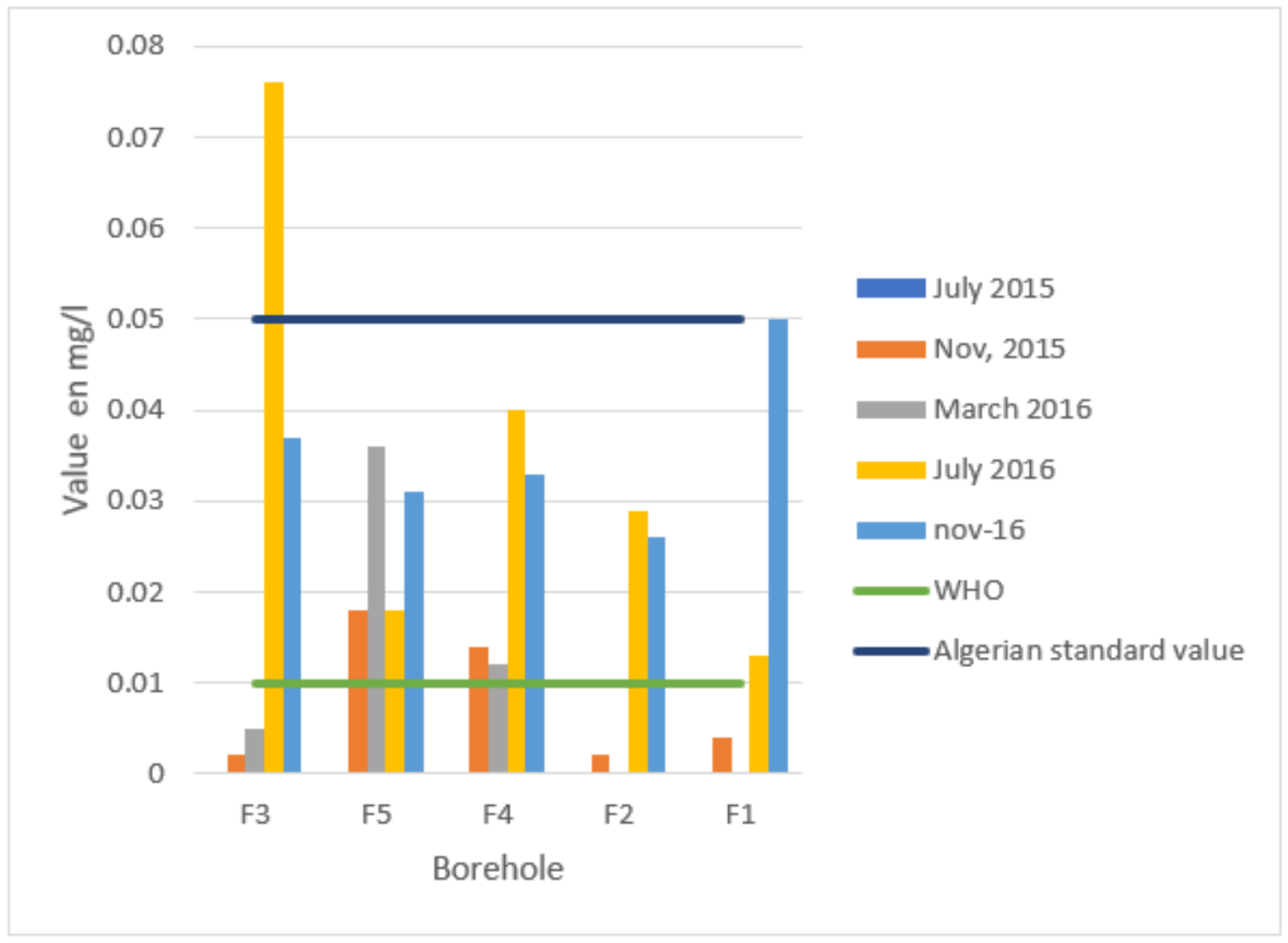

Figure 9

Change in $\mathrm{Pb}$ levels in groundwater 


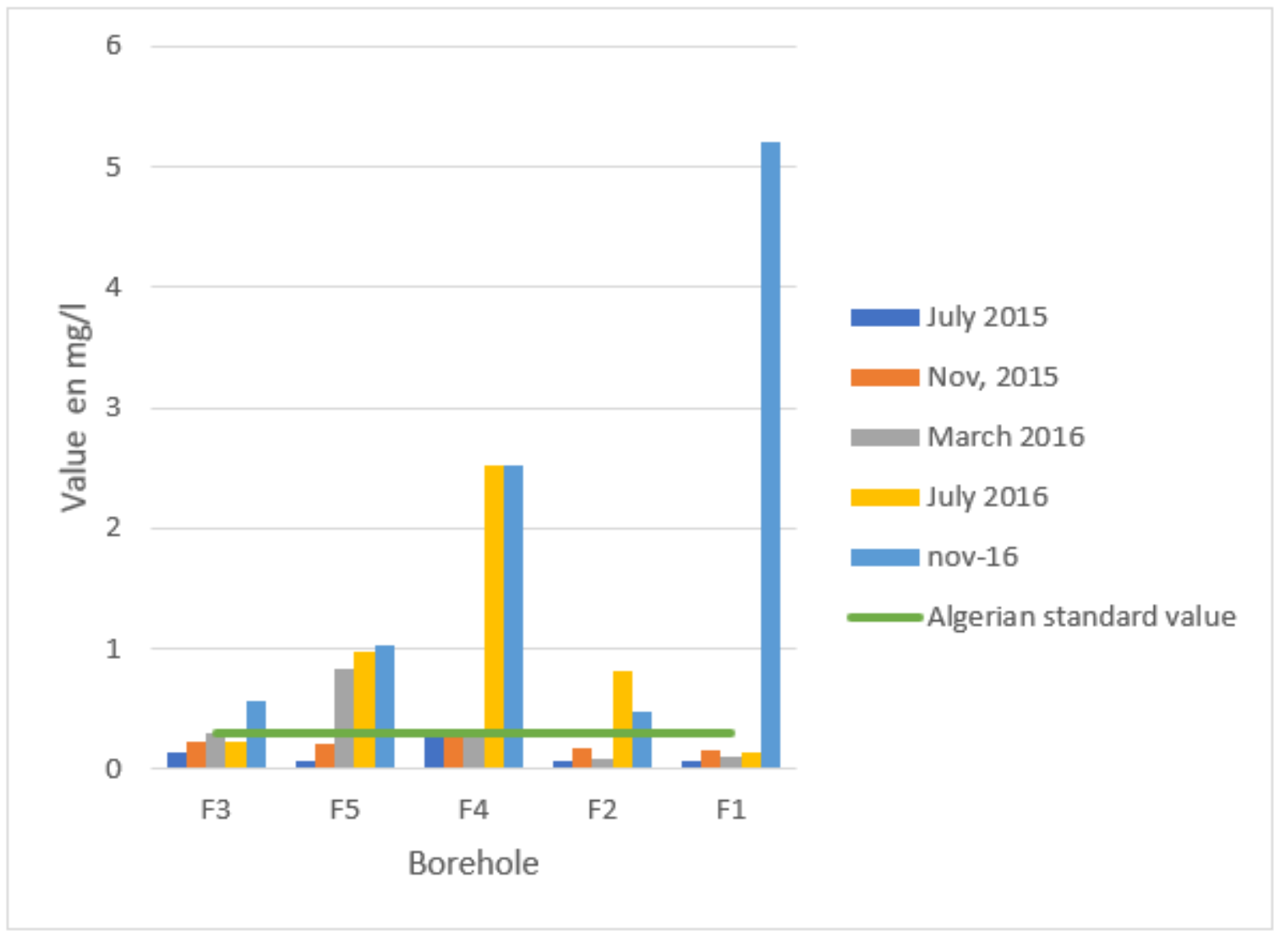

Figure 10

Change in Fe levels in groundwater 